\title{
CULTURAL APPROPRIATION AND DESTINATION BRANDS
}

\author{
Joao FREIRE* \\ IPAM, Universidade Europeia, Portugal, e-mail: joao.freire@universidadeeuropeia.pt
}

Rosane GERTNER

City University of New York, Marketing Department, USA, e-mail: rosane.gertner@ csi.cuny.edu

\section{David GERTNER}

Thunderbird School of Global Management, Faculty Associate, Master of Global Management, USA, e-mail: gertner@gmail.com

\begin{abstract}
Citation: Freire, J., Gertner, R., \& Gertner, D. (2022). CULTURAL APPROPRIATION AND DESTINATION BRANDS. GeoJournal of Tourism and Geosites, 40(1), 79-88. https://doi.org/10.30892/gtg.40109-805
\end{abstract}

\begin{abstract}
Increasing public scrutiny, intensifying consumers' demand for political correctness, and rising concerns about cultural appropriation have pressed marketers to reassess products, brand names, logos, mascots, claims, advertising, and so forth. This article reports on the evaluation of consumers' awareness of cultural appropriation within a destination branding context by means of an experimental design. The study tested the impact of priming participants with information about cultur al appropriation on their attitudes toward local souvenir sales, theatrical performances, and the use of artifacts by outsiders. A questionnaire was applied to 201 people. Results suggest that the concept of cultural appropriation is little understood. On the other hand, those participants who were introduced to the concept displayed some significantly different perceptions about its impact compared to those who were not. Hence, place marketers should assess the extent to which cultural appropriation could
\end{abstract}

Key words: cultural appropriation, branding, destination marketing, destination brands, place branding, political correctness

$* * * * * *$

\section{INTRODUCTION}

Consumers' adoption of political correctness as a driver of behavior has recently intensified. Political correctness is defined as "the avoidance of forms of expression or action that are perceived to exclude, marginalize, or insult groups of people who are socially disadvantaged or discriminated against" (Lexico.com, n.d.). The topic encompasses a myriad of issues, including diversity, racism, stereotyping, sexism, gender roles, and sexual harassment. One related concern that has received growing attention is cultural appropriation, "the unsuitable, unauthorized, or objectionable use of cultural elements in a context other than that of the culture by outsiders who might lack understanding and/or respect for the culture in question" (Gertner, 2019: 873). The growing demand for political correctness, as well as denunciations of cultural appropriation, is observed in numerous contexts. In fashion, for example, Victoria's Secret has been repeatedly criticized for using Mexican, Chinese, African, and other groups' cultural elements and symbols to adorn models during its fashion shows (Anderson, 2017; Harper's BAZAAR, 2017). In addition, numerous celebrities and pop artists have been recurrently censured for politically incorrect statements or for using elements and symbols of cultural, ethnic, or racial groups to which they do not belong in public appearances and performances (Twersky, 2019; Rae, 2019). Likewise, politicians have found that their comments and actions in relation to sensitive subjects, such as ethnicity and race, are closely scrutinized by the public (Perrett, 2020). Political correctness and cultural appropriation concerns have significantly impacted traditional marketers. Public opinion has pressed several brands to review names, logos, claims, and mascots, for example. In 2020, for instance, allegations of racial stereotyping drove Quaker Oats to delete the image of a black woman from the logo and packages of the Aunt Jemima brand of syrups and pancake mixes (Heil, 2020; Norris, 2020; Valinsky, 2020). In the same year, Mars Food announced that the company would reevaluate the visual identity of its Uncle Ben's rice brand, which included the image of an elderly African American man. Various other brands were expected to follow suit in reviewing their advertising, brand names, mascots, and logos in response to criticisms of racism and stereotyping, including Cream of Wheat cereal and Darkie toothpaste (McEvoy, 2020).

After decades of accusations that the Redskins, the name of the NFL team based in Washington, DC, was insulting to Native Americans, the owner Dan Snyder and the coach Ron Rivera announced that name and logo would be altered (Sanchez, 2020). Finally, concerns about the ongoing discussion on cultural appropriation led Land O'Lakes butter to remove the image of a Native American woman from its logo and instead stress that its product was "Farmers Owned" on the newly designed package (Wu, 2020). The discussion of cultural appropriation has lately reached primetime TV, with the writers of ABC's sitcom The Conners bringing the issue to the fore at least twice in two years. One article about an episode aired in October 2018 was titled: "The Conners' Halloween episode showed that cultural appropriation can be complicated, but it's a necessary conversation" (Pomarico, 2020). In the spring of 2020, in the season 2 finale, one the leading characters, Jackie, played by Laurie Metcalf, stood at the US-Mexico border, confronting Americans returning

\footnotetext{
* Corresponding author
} 
from Mexico wearing sombreros and holding maracas by asking if they were not ashamed of appropriating Mexican culture (Long, 2020). Cultural appropriation was also addressed by the Netflix series The Politician, specifically in episode 3 of season 2, which was titled "Cancel Culture." In the episode, a picture of Payton Hobart, Ben Platt's character, at age six wearing a "Jerome" costume in Halloween is used to discuss the concept of cultural appropriation. Viewers are taught that for members of the culture, what is referred to as 'cultural borrowing' is in fact 'cultural stealing' and 'cultural appreciation' is actually 'cultural appropriation.' The cultural appropriation debate should be seen as particularly significant for destination brands, primarily for tourist destinations that promote local cultures. According to Gertner (2019:873), "A growing number of critics believe destination brands in general, and tourist destinations in particular, have exploited indigenous groups for the commercial purpose of entertaining visitors". This author alerts readers about "the importance, implications, and risks of cultural appropriation to the future of destination image, reputation, attractiveness, and sustainability" (Gertner, 2019:873). The destination marketing, management, and branding literature on this topic is scant. Furthermore, it is not clear whether consumers broadly speaking, and tourists in particular, understand what cultural appropriation is and how they relate to it. For these reasons, this investigation attempts to test quantitatively whether people are aware of cultural appropriation and how they relate to the concept in the tourism context. Two questions guide the present analysis: What is cultural appropriation in a tourism context in the eyes of consumers? and Does advertising/education (priming) affect the assessment of the dimensions of cultural appropriation by consumers?

\section{LITERATURE REVIEW}

Culture and Cultural Appropriation

Culture is a set of specific patterns of ideas, values, beliefs, and behaviors held by a community (Wang, 2001; McFee and Degge, 1977). Sharing culture across communities is part of human nature. The concept of cultural appropriation, however, calls into question this behavior and may prevent future cultural exchange (Young, 2015).

The roots of the concept of cultural appropriation are found in the early 1990s in the field of indigenous studies (Fung, 1993). In its simplest and most neutral formulation, the term refers to the adoption or adaptation by people of one culture of an aspect of the culture of some other people (Heyd, 2003; Hladki, 1994). This assumes the two peoples are on an equal footing; in general, however, an asymmetrical relationship is presupposed, so that cultural appropriation is "speaking for others or representing them in fictional as well as legal, social, artistic, and political work [as] appropriate or proper, especially when individuals or groups with more social, economic, and political power perform this role for others without invitation" (Hart, 1997:137). Crane (2018) points out that the appropriation of culture never happens without a corresponding appropriation of labor and human lives. Furthermore, when one culture borrows forms from another culture, stereotypes can be created (Said, 1985) and may have negative effects on minoritized cultures (Kulchyski, 1997).

The modification of minority cultures' artifacts, traditions, and rituals does not necessarily consider their original meanings and, in some cases, may offend the artists and communities who originated them. Consequently, the discussion about cultural appropriation has many aspects, including its ethical, legal, and political repercussions (Young and Brunk, 2009; Matthes, 2019). Most early discussions of cultural appropriation had to do with the ownership of archaeological finds, museum pieces, and visual art, such as paintings and pottery, and soundtracks of songs and music. Numerous indigenous and non-indigenous protesters and scholars began to develop a legal-ethical outline for the understanding of cultural property, what constituted its appropriation, and the restitution of property to indigenous nations (Young and Brunk, 2009). As an example, a sacred Blackfoot buckskin shirt that had once been the property of the indigenous chief Crowfoot and was displayed in the Royal Albert Memorial Museum in the UK was repatriated to the Siksika Nation in Canada (Bakare, 2020). Cultural appropriation is not always an unadulterated portrayal of another culture; it can take the form of a distorted image reflecting political, economic, and cultural domination (Hooks, 2006). Wesaw (1994) argues that corporations in white society have marketed products with Indian brand names and logos in a way that alters and trivializes Native American cultures, even when logos and labels such as the Washington Redskins, the Crazy Horse Malt Liquor Label, and the cars Pontiac and Cherokee ostensibly praise Native Americans for their courageousness and nobility.

An increasing number of critics are questioning the 'morality' of the "misrepresentation, misuse, and theft of the stories, styles, and material heritage of people who have been historically dominated and remain socially marginalized" (Matthes, 2016: 343). According to Wesaw (1994), "Indian" labels as used by "White Society" create stereotypes and thus weaken Native American efforts to elevate tribal standards. For example, the word "Indian" can refer to a "noble" or a "savage" or an "evil" or an "environmentalist." In other words, "Indian" can be anything the "White Society" wishes or does not wish it to be. For Wesaw (1994), these prejudiced and deceptive marketing and consumption practices denigrate true Native culture, causing great damage to Native American communities. In addition, Wesaw cites Michael Dorris, a Native American author, who points out that Indian images and symbols sell sports teams, sports gear, toys, foods, home products, incense, tobacco, beverages, automobiles, and so forth though no compensation is offered to indigenous people. Yet in some cases, companies even claim that that the sale of their products benefits Native communities (Wesaw, 1994).

This practice has negatively impacted the ability of Native Americans to market goods they have produced themselves. Wesaw (1994) states that consumers who are willing to pay more for authentic products have become confused, with the consequence that Native American access to this profitable market is reduced or blocked entirely. In 2012, the Navajo nation sued Urban Outfitters, demanding the clothing retailer remove the "Navajo" name from its products, based on the Indian Arts and Crafts Act of 1990, a truth-in-advertising law that prohibits misrepresentation in the marketing of Indian arts and craft products within the US. The 1935 Indian Arts and Crafts Act had established criminal penalties for marketing and selling objects that misrepresented Indian products, but did not impose major consequences on those who 
misrepresented fake arts and crafts as Indian produced and marketed them as "Indian Made." In addition, it required that a violation be proven, and there was very little enforcement. Due to the subsequent enormous increase in sales (in the billions of dollars) in the US Indian arts and crafts market of products wrongly represented as having been made by Indians, Congress passed the Indian Arts and Crafts Act of 1990. The act states, "It is illegal to offer or display for sale, or sell any art or craft product in a manner that falsely suggests it is Indian produced, an Indian product, or the product of a particular Indian or Indian tribe or Indian arts and crafts organization, resident within the United States" (https://www.doi.gov/iacb/act).

Nowadays, it is difficult to define what can and cannot be categorized as cultural appropriation (DeBoer, 2016). Because cultural appropriation has just recently gained high awareness among the general public, due to the increased discussions of this issue in social networks and media coverage, an enormous range of situations have been interpreted as cultural appropriation. These run the gamut from the adoption of the African women's head wrap (Dhuku) by Westerners to the use of minority groups' original designs, symbols, or mascots by Western entities such as sport teams, product manufacturers, and colleges (DeBoer, 2016). As mentioned above, sharing cultural elements across different societies is an intrinsic part of human behavior. Nonetheless, Lynskey (2014) questions the right of nonindigenous groups to wear traditional outfits of indigenous people. This and other forms of cultural appropriation have been receiving harsh criticism on the basis that they are associated with those dominant in society taking aspects of minority cultures, modifying them, and profiting from them without benefiting the minority cultures (Young, 2010; Scafidi, 2005). Young and Brunk (2009) highlight three kinds of cultural appropriation that seem to be ethically dubious: (1) violating the property rights of a culture, (2) undermining the identity of a culture, and (3) disrespecting cultural norms, which may offend the members of the affected culture. On the other hand, cultural appropriation can be perceived as morally acceptable.

Some authors suggest that culture needs to be shared, understood, and celebrated. Thus, the term 'appropriation' should be replaced by 'borrowing' (Matthes, 2016; Han, 2019). Even when minority communities' members are offended by acts of cultural appropriation by dominant cultures, the acts may not be ones of wrongdoing (Young, 2005). Chanel attracted criticism and equally avid defenses for appropriating symbols of Native American dress in its ParisDallas Métiers d'Art 2013/2014 collection. A Chanel spokesperson wrote to fashionista.com: "The Chanel Paris-Dallas Métiers d'Art 2013/2014 collection is a celebration of the beauty of Texas. Native Americans are an integral part of Texas' rich history and culture and the feather headdress, a symbol of strength and bravery, is one of the most visually stunning examples of creativity and craftsmanship. We deeply apologize if it has been misinterpreted or is seen as offensive as it was really meant to be a tribute to the beauty of craftsmanship" (Indvik, 2013).

\section{Cultural Appropriation in the Tourism Context}

The literature has proven the value of cultural tourism (Richards, 2003; Rojekand and Urry, 1997; Sdrali and Chazapi, 2007). Prior studies have shown an increased interest in culture, indicating that more tourists are looking for genuine and meaningful cultural experiences that differ from those of their home country when visiting a destination (Freire, 2005; Barbieri and Mahoney, 2010; Valle et al., 2011; Hassan, 2015). Thus, the availability of cultural attractions is crucial to drawing a broader range of tourists to a destination (Freire, 2005; Agarwal and Brunt, 2006; Molinillo and Japutra, 2015; Hernández-Mogollón et al., 2018; Freire and Gertner, 2020). In addition, research has shown that cultural attractions are strong promoters of tourism and influence destination image formation (Gursoy et al., 2004; Getz, 2008; Valle et al., 2011).

Local cultures are also perceived as a significant component in the enhancement of destination images and post-trip tourist satisfaction (Richards and Wilson, 2004; Chapman and Speake, 2010). Richards (1996, 2005) provides both technical and conceptual definitions of cultural tourism. According to the former, "Cultural tourism means all movements of persons to specific cultural attractions, such as heritage sites, artistic and cultural manifestations, arts and drama outside their normal place of residence" (1996:24); the latter states that it "is the movement of persons to cultural attractions away from their normal place of residence, with the intention to gather new information and experiences to satisfy their cultural needs" (2005:24). Richards (2003) points out that these definitions do not recognize that cultural attractions are dynamic, which makes it difficult to identify what is 'purely' cultural or 'entertainment based.' While Leask (2010) contends that cultural attractions should be resources for local communities, some tourist destinations have been criticized for exploiting indigenous groups for commercial purposes and usurping indigenous peoples' rituals to create tourist attractions (O’Daly, 2017). For example, it is estimated that 85 percent of aboriginal arts and crafts sold to tourists in Australia as genuine aboriginal art is fake and imported (NITV, 2017).

Greenwood (1989) discusses the impact of tourism merchandising, souvenirs, performances, clothing, etc., in a local community from an anthropological viewpoint: "The anthropological perspective enables us to understand why the commoditization of local culture in the tourism industry is so fundamentally destructive and why the sale of 'culture by the pound' as it were, needs to be examined by everyone involved in tourism” (p. 131). Nonetheless, there is also the perspective that tourism does not necessarily equate with the commercialization of local cultures and the loss of their unique characteristics. Tourism can be seen as a way to protect and promote cultural diversity. From this perspective, the concept of destination branding can be seen as an inform response for local sustainable development, the promotion and protection of local community rituals, and the improvement of the image of destinations (Freire, 2005). Destination images are constructed of several components, culture being one of them (Gertner and Freire, 2018; Echtner and Ritchie, 1993; Valle et al., 2011; Hassan, 2015). However, reports of abuses and exploitation may negatively influence visitors' perception of a destination image, which, ultimately, can diminishes their desire to visit a place. Thus, in the context of destination branding, destination image, tourism, and hospitality, negative publicity associated with the appropriation of culture can be very damaging, if a locale's economy is largely based on tourism and hospitality services (Gertner, 2019). 


\section{MATERIAL AND METHODS}

\section{Research Question}

This investigation was designed to test the following research question: Do consumers understand the concept of cultural appropriation in a tourism context?

\section{Sample}

Data were collected using Pollfish, an online research company that partners with other applications to access participants for data collection. The final sample comprised 201 participants, 56 percent female and 44 percent male, all from the US. In order to gather responses from more-experienced travelers, the questionnaire was only administered to individuals who had travelled for leisure outside of the continental US at least once and were older than 24 years, that is, were born after 1996. In terms of age, 19 percent of participants were born between 1946 and 1964, 31.5 percent between 1965 and 1980, and 49.5 percent between 1981 and 1996. No significant differences in responses were found based on gender or age group. Lastly 45 percent of the sample read a text about cultural appropriation (Figure 1) before responding the questionnaire, these participants became part of the "priming" group, and 55 percent of the participants answered the questionnaire without reading the text, these participants became part of the "non-priming" group.

\section{Research Instrument}

Because the academic study of cultural appropriation is relatively young, the authors ended up developing their own instrument based on a questionnaire to study its significance. The questionnaire was composed of 35 variables, or statements, that measured the impact of tourists on local communities. These variables were arranged in three groups or dimensions (Table 1) and 7-point Likert scales were used to measure participants' level of agreement with the statements. The investigation's premise is that cultural appropriation, in the context of tourism, can be manifested in three offerings typically available to tourists. Those three offerings are: culture-related souvenirs, theatrical cultural performances, and culturerelated artifacts and outfits. The first dimension, The role and meaning of souvenirs sold to and bought by tourists, comprised of 12 variables, examined the role and meaning of souvenirs bought by tourists, using a 7-point Likert scale (Table 2). Dimension 2 (Table 3), also comprised of 12 variables, measured participants' level of agreement with 12 statements regarding Local theatrical performances catering to tourists, such as performances that present local dances, music, rituals, and religious ceremonies in hotels, nightclubs, and other venues to entertain and bring awareness of the local culture to tourists.

Table 2. Dimension 1variables and associated survey questions

Using the scale provided, please indicate the extent to which you agree or disagree with each of the following statements:

1 . When tourists buy souvenirs, they demonstrate interest in the local culture and people

2 . When tourists buy souvenirs, they bring home memories of their cultural experiences

3 . When tourists bring home souvenirs, they demonstrate appreciation for the culture and local people"

4. When tourists buy souvenirs, they help to preserve the local culture"

5 . When tourists buy souvenirs, they help local and indigenous people financially"

6. Mass-produced souvenirs banalize local cultures and its sacred symbols"

7 . Tourists should only buy authentic objects made by local craftspeople or authorized replicas

8 . It is morally wrong to sell unauthorized reproductions of traditional objects from a culture to tourists"

9 . Tourists should make sure that the souvenirs they buy are not offensive to the members of the local culture

10 . Tourists who buy 'indigenous' ceremonial and sacred objects, without understanding their meaning disrespect the local culture and people

11.It is harmless when tourists use traditional objects from a culture in a different context, such as to decorate their homes

12 . The sales of souvenirs that reproduce objects or symbols with cultural significance should be approved by local and indigenous people

Table 3 Dimension 2 variables and associated survey questions

Many destinations offer shows that display local dances, music, rituals, and even religious ceremonies, with professional performers, in hotels, night clubs and other venues, to entertain tourists and enlighten them about local cultural elements. Using the scales provided, please indicate the extent to which you agree that these theatrical presentations:

13. Help tourists to experience another culture

14. Educate tourists about local cultures

15. Offer a fair illustration of the local customs and rituals

16. Represent a form of appreciation for the local culture

17. Are good cultural learning experiences

18. Lack authenticity

19. Represent a form of appropriation of the culture

20. Do not reflect the local culture elements

21. Undermine historical and cultural significance

22. Are disrespectful to local and indigenous people

23. Can cause harm to the culture

24. Stereotype local and indigenous people
Table 4. Dimension 3 variables

and associated survey questions

Using the scales provided below, please indicate the extent to which you believe that traditional outfits, accessories, and textiles that have cultural, historical, or religious significance and meaning to local and indigenous people bought by tourists: 25. Promote the culture

26. Offer meaningful memories of the culture

27. Are disrespectful

28. Represent a form of appropriation of the culture

29. Are offensive to local and indigenous people

30. Make locals feel uneasy

31. Should not be used by tourists

32. Should not be taken out of context

33. Should not be bought

34. Should not be worn as a costume

35. Should not be used as an ornamental object 
Lastly, Dimension 3 (Table 4), comprised of 11 variables, was measured by means of 11 questions intended to evaluate participants' attitudes toward the purchase and use by tourists of traditional items that have cultural significance, such as outfits, accessories, and textiles.

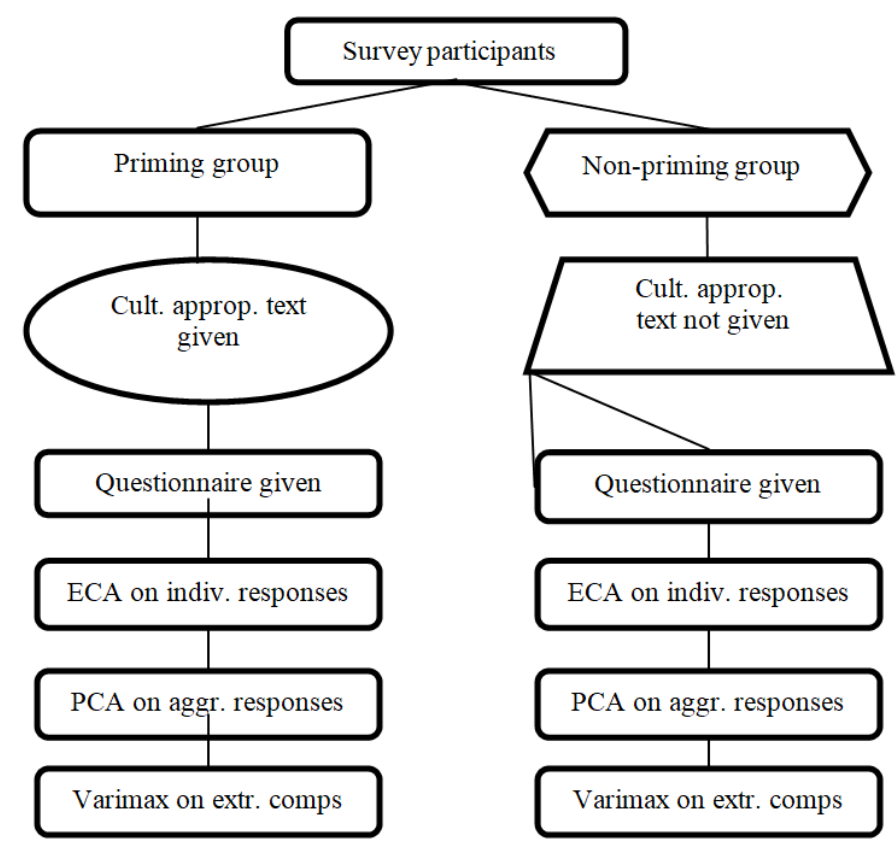

Figure 1. Survey and analysis methodology

\section{Method}

This investigation adopted an experimental design. In an experiment, study participants are allocated in different groups and their answers are compared to test the existence of statistically significant differences between the groups' responses (McLeod, 2017) (Figure 1).

In this study, participants were randomly assigned to two groups, "priming" or "nonpriming": "Priming is a psychological process in which exposure to a stimulus activates a concept in memory that is then given increased weight in subsequent judgment tasks" (Lavrakas, 2008: 612).

All participants in this study were asked to answer the same questionnaire. However, the members of the "priming" group, before answering the questions, were requested to read a short text that introduced the concept of cultural appropriation and provided examples of how purchasing souvenirs, attending local theater representations, and the use of artifacts by outsiders might be offensive to the local people (Table 5).

Table 5 Text that preceded the questionnaire for participants in the "priming" group

- An increasing number of local and indigenous people in numerous popular destinations resent that the tourism industry has misused their cultural elements for commercial purposes. Also, research has revealed that native people do not believe that tourism has had a role in preserving their language and culture. Many community members feel disrespected, particularly when tourists use cultural elements out-of-context, without understanding their history and meaning. Examples of such practices include:

- Sales of cheap, mass-produced, imported, and unlicensed reproduction of images, art, and objects that have special cultural significance to locals and indigenous people.

- Use by tourists of clothing and accessories out-of-context or as a costume such as masks, face paintings, ornaments, objects, clothing, accessories, and images associated with "El Dia de Los Muertos," a religious holiday and sacred date, when Mexican families gather to remember and honor deceased loved ones.

- Misrepresentation of local habits and rituals. For example, tiki bars, torch-lighting ceremonies, and fire knife dances are not Hawaiian. Polynesians have never worn coconut bras, grass skirts and wouldn't give plastic leis. "Dressing up as a Hawaiian" is considered offensive, since "being Hawaiian" isn't a costume. Also, the use of "aloha" has been so far removed from any Hawaiian cultural context and has become meaningless.

The ANOVA technique was used to test whether reading the informative text (priming) influenced the dimensions extracted from the factor analysis. Exploratory factor analysis (EFA) was the statistical method chosen to test the appropriateness of the three dimensions initially posited, as well as to help identify new relationships among the 35 variables and possibly suggest a different way to regroup them. Individuals' responses were therefore aggregated and attribute correlation matrices were calculated and subjected to principal component analysis (PCA). For factor extraction, PCA was the method of choice "to extract the maximum possible variance, with successive factoring continuing until there is no further meaningful variance left" (Ding, 2018: 56). The components extracted were then orthogonally rotated using the varimax procedure; the varimax rotation is a solution "that makes it easy to identify each variable with a single factor" (Ivancevic et al., 2008: 161).

\section{RESULTS}

Data Reduction - Creating New Variables

After conducting a factor analysis that included all 35 variables, the KaiserMeyer-Olkin (KMO) Measure of Sampling Adequacy was used to test validity. The KMO obtained was 0.902 , which by being $>0.5$ is considered to be an excellent positive indicator for the use of factor analysis as a tool for variable reduction (Table 6). The significance level of Bartlett's Test of Sphericity is $<0.05$, indicating that the correlation matrix is not an identity matrix; therefore, the variables are related and suitable for structure detection (Malhotra and Dash, 2016).

PCA was used to extract the factors, which were then orthogonally rotated using the varimax procedure (Table 7). Using these two procedures, six components were extracted. These six components explained 67.178 percent of the total variance (Table 8). After observing the results, the researchers categorized and defined each of the six factors extracted (Table 9).
Table 6. KMO Measure of Sampling Adequacy and Bartlett's Test

\begin{tabular}{|l|c|c|}
\hline \multicolumn{2}{|c|}{ Kaiser-Meyer-Olkin } & .902 \\
Measure of Sampling Adequacy & \\
\hline Bartlett's & Approx. chi-square & 4609.502 \\
\cline { 2 - 3 } Test of & Df & 561 \\
\cline { 2 - 3 } Sphericity & Sig. & 0.000 \\
\hline
\end{tabular}


Table 7. Rotated Component Matrix ${ }^{\mathrm{a}}$

\begin{tabular}{|c|c|c|c|c|c|c|}
\hline \multirow{2}{*}{ Table 7. Rotated Component Matrix ${ }^{\mathrm{a}}$} & \multicolumn{6}{|c|}{ Component } \\
\hline & 1 & 2 & 3 & 4 & 5 & 6 \\
\hline 9. Tourists should make sure that the souvenirs they buy are not offensive to the members of the local culture & .813 & .074 & -.073 & .037 & .043 & .142 \\
\hline $\begin{array}{l}\text { 10. Tourists who buy 'indigenous' ceremonial and sacred objects, without understanding their } \\
\text { meaning, disrespect the local culture and people }\end{array}$ & .797 & .128 & -.003 & -.020 & .239 & .032 \\
\hline 7. Tourists should only buy authentic objects made by local craftspeople or authorized replicas & .756 & .178 & .033 & .043 & .172 & .015 \\
\hline 8. It is morally wrong to sell unauthorized reproductions of traditional objects from a culture to tourists & .755 & .180 & .012 & .088 & .137 & .091 \\
\hline 6. Mass-produced souvenirs banalize local cultures and their sacred symbols & .655 & .107 & .117 & -.072 & .248 & .123 \\
\hline $\begin{array}{l}\text { 12. The sales of souvenirs that reproduce objects or symbols with cultural significance should be } \\
\text { approved by local and indigenous people }\end{array}$ & .636 & .284 & .129 & -.024 & .232 & .115 \\
\hline 34. Should not be worn as a costume & .566 & .493 & -.127 & -.240 & .101 & .037 \\
\hline 32. Should not be taken out of context & .549 & .368 & -.045 & .023 & -.005 & .160 \\
\hline $\begin{array}{l}\text { 11. It is harmless when tourists use traditional objects from a culture in a different context, such as } \\
\text { to decorate their homes }\end{array}$ & -.495 & -.292 & .254 & .240 & .283 & -.027 \\
\hline 33. Should not be bought & .348 & .752 & -.116 & -.015 & .152 & .109 \\
\hline 27. Are disrespectful & .221 & .743 & -.041 & -.130 & .329 & .152 \\
\hline 29. Are offensive to local and indigenous people & .233 & .741 & -.079 & -.076 & .348 & -.046 \\
\hline 31. Should not be used by tourists & .383 & .723 & -.080 & -.188 & .274 & .044 \\
\hline 30. Make locals feel uneasy & .168 & .676 & -.019 & -.140 & .441 & -.058 \\
\hline 35. Should not be used as an ornamental object & .480 & .625 & -.066 & -.144 & .109 & .127 \\
\hline 14. Educate tourists about local cultures & .020 & -.072 & .821 & .176 & -.044 & .029 \\
\hline 16. Represent a form of appreciation for the local culture & -.039 & -.055 & .799 & .248 & -.113 & -.045 \\
\hline 17. Are good cultural learning experiences & .051 & -.088 & .763 & .343 & -.235 & .079 \\
\hline 13. Help tourists to experience another culture & .048 & -.020 & .743 & .319 & -.234 & .092 \\
\hline 15. Offer a fair illustration of the local customs & -.034 & -.011 & .675 & .334 & -.192 & .173 \\
\hline 26. Offer meaningful memories of the culture & .007 & -.428 & .461 & .396 & -.054 & .063 \\
\hline 25 . Promote the culture & -.142 & -.424 & .451 & .446 & .073 & .081 \\
\hline 1. When tourists buy souvenirs, they demonstrate interest in the local culture and people & -.004 & -.045 & .217 & .838 & -.048 & .047 \\
\hline 3. When tourists bring home souvenirs, they demonstrate appreciation for the culture and local people & .004 & 0.023 & 3.242 & .821 & -.099 & -.066 \\
\hline 4. When tourists buy souvenirs, they help to preserve the local culture & .001 & -.128 & .257 & .741 & .009 & .106 \\
\hline 2. When tourists buy souvenirs, they bring home memories of their cultural experiences & -.052 & -.177 & .263 & .645 & -.139 & .024 \\
\hline 5. When tourists buy souvenirs, they help local and indigenous people financially & -.005 & -.204 & .370 & .595 & -.080 & -.003 \\
\hline 18. Lack authenticity & .040 & .024 & -.178 & -.103 & .747 & -.012 \\
\hline 21. Undermine historical and cultural significance & .236 & .225 & -.096 & -.021 & .680 & .189 \\
\hline 23. Can cause harm to the culture & .318 & .360 & -.083 & -.104 & .678 & .032 \\
\hline 22. Are disrespectful to local and indigenous people & .296 & .356 & -.145 & -.070 & .673 & .091 \\
\hline 20. Do not reflect the local culture elements & .055 & .292 & -.330 & .095 & .662 & .114 \\
\hline 24. Stereotype local and indigenous people & .321 & .254 & -.091 & -.243 & .605 & .008 \\
\hline 28. Represent a form of appropriation of the culture & .225 & .094 & .153 & -.074 & .133 & .838 \\
\hline 19. Represent a form of appropriation of the culture & .308 & .073 & .098 & .245 & .112 & \begin{tabular}{|l}
.787 \\
\end{tabular} \\
\hline
\end{tabular}

Table 8. Total variance explained

\begin{tabular}{|c|c|c|c|}
\hline \multirow{2}{*}{ Component } & \multicolumn{3}{|c|}{ Rotation Sums of Squared Loadings } \\
\cline { 2 - 4 } & Total & $\%$ of Variance & Cumulative \% \\
\hline 1 & 5.048 & 14.847 & 14.847 \\
\hline 2 & 4.488 & 13.201 & 28.049 \\
\hline 3 & 4.010 & 11.794 & 39.843 \\
\hline 4 & 3.889 & 11.439 & 51.282 \\
\hline 5 & 3.813 & 11.214 & 62.496 \\
\hline 6 & 1.592 & 4.682 & 67.178 \\
\hline
\end{tabular}

Note: Extraction method: principal component analysis

In order to measure the internal consistency of each factor, each of the six factors was tested for reliability using Cronbach's alpha (Table 10). For factors $1,3,4$, and 5 the Cronbach's alpha value is between 0.8 and 0.9 , which is considered a good value. Factor 2 has a Cronbach's alpha higher than 0.9 , meaning that in terms of internal consistency, the factor has Table 9. Interpretation of the six factors extracted

Factor 1 - Attitudes toward cultural-related souvenirs

Factor 2 - Attitudes toward cultural-related outfits

Factor 3 - Attitudes toward attendance of theatrical cultural performances as a learning experience

Factor 4 -Attitudes toward souvenirs as an expression of cultural appreciation Factor 5-Impact of theatrical cultural performances on local culture and people Factor 6-Cultural appropriation

Table 10. Cronbach's alpha value for the six factors

\begin{tabular}{|c|c|c|c|c|}
\hline & $\begin{array}{c}\text { Cronbach's } \\
\text { alpha }\end{array}$ & $\begin{array}{c}\text { Cronbach's alpha based } \\
\text { on standardized items }\end{array}$ & $\mathrm{N}$ & $\begin{array}{c}\text { Internal } \\
\text { consistency }\end{array}$ \\
\hline Factor 1 & .813 & .810 & 9 & Good \\
\hline Factor 2 & .918 & .919 & 6 & Excellent \\
\hline Factor 3 & .894 & .896 & 7 & Good \\
\hline Factor 4 & .861 & .863 & 5 & Good \\
\hline Factor 5 & .877 & .875 & 6 & Good \\
\hline Factor 6 & .751 & .752 & 2 & Acceptable \\
\hline
\end{tabular}

an excellent value. Finally, Factor 6 has a Cronbach's alpha between 0.7 and 0.8 , which is considered an acceptable value. Consequently, the analysis suggested that, instead of the three dimensions initially proposed, the 35 variables included in the study should be grouped in six factors. The six factors, however, are directly connected to the three dimensions initially proposed, as elaborated below. 
Factor 1, defined as Attitudes toward culture-related souvenirs, includes all the variables that could be used to define what cultural appropriation is in the case of souvenirs. This factor is aligned with Dimension $1-$ Role and meaning of souvenirs sold to and bought by tourists.

Factor 2, defined as Attitudes toward culture-related outfits, is aligned with Dimension 3 - Use of cultural artifacts by nonlocal people.

Factor 3, defined as Attitudes toward attendance of theatrical cultural performances as a learning experience, relates to the positive impact theatrical cultural performances as learning experiences have on tourists. This factor indicated that these elements are positive and not negative; therefore, this factor cannot be seen as an element of cultural appropriation. If cultural appropriation was a clearly accepted concept, the loadings of each variable of this factor would be part of Factor 5, though the loadings would be negative. The negative loading would suggest negative correlations with the other variables.

Factor 4, defined as positive Attitudes toward souvenirs being an expression of cultural appreciation, should be included in Dimension 1 - Role and meaning of souvenirs sold to and bought by tourists. Furthermore, the variables of this factor should be part of Factor 1, but with a negative loading, which would represent a negative correlation with the variables of Factor 1.

Factor 5, defined as the Impact of theatrical cultural performances on local culture and people, represents Dimension 3 - Use of cultural artifacts by non-local people. Therefore, Factor 5 can be seen as an element of cultural appropriation.

Factor 6, defined as Cultural appropriation, includes the two variables related to cultural appropriation. Interestingly, these two variables were aggregated and were not included in any of the other factors. This points to a degree of misunderstanding about what the term "cultural appropriation" means. If there was a clear understanding of the meaning of "cultural appropriation," it is expected that the expression of these variables would be included in Factor 1, 2, or 5.

These results indicate that despite its currency within the media and certain segments of society, cultural appropriation is not a clearly defined concept, and consequently it is not understood by the public at large.

\section{Analysis of Variance Test - ANOVA}

With this new set of six factors in hand, ANOVA was used to test for differences between the "priming" and the "non-priming" groups. This analysis demonstrated that there were significant differences between the two groups in only two factors, Factor 5 - Impact of theatrical cultural performances on local culture and people, and Factor 6 Cultural appropriation (Table 11). The ANOVA results indicate that participants exposed to the text about cultural appropriation, the "priming' group, believed that Theatrical cultural performances on local culture and people had a more negative impact on the local communities than did study participants who were not exposed to the text ("nonpriming group"). The exposure to the text prior to the questionnaire application also significantly affected the evaluation of cultural appropriation, yielding significant differences in the answers of the two groups, with the "priming" group being more sensitive to the matter. Once again, these findings confirm the perception that cultural appropriation has been discussed in the media but is poorly understood or accepted by society as a whole.

Table 11. ANOVA test of differences between "priming" and "non-priming" groups for the six factors

\begin{tabular}{|c|c|c|c|c|c|c|}
\hline & & Sum of squares & Df & Mean square & $\mathrm{F}$ & Sig. \\
\hline \multirow{3}{*}{ Factor 1 for analysis $6 *$ Prime } & Between groups & 1.817 & 1 & 1.817 & 1.825 & .178 \\
\hline & Within groups & 198.183 & 199 & .996 & & \\
\hline & Total & 200.000 & 200 & & & \\
\hline \multirow{3}{*}{ Factor 2 for analysis $6 *$ Prime } & Between groups & .012 & 1 & .012 & .012 & .914 \\
\hline & Within groups & 199.988 & 199 & 1.005 & & \\
\hline & Total & 200.000 & 200 & & & \\
\hline \multirow{3}{*}{ Factor 3 for analysis $6 *$ Prime } & Between groups & .030 & 1 & .030 & .030 & .864 \\
\hline & Within groups & 199.970 & 199 & 1.005 & & \\
\hline & Total & 200.000 & 200 & & & \\
\hline \multirow{3}{*}{ Factor 4 for analysis $6 *$ Prime } & Between groups & .079 & 1 & .079 & .079 & .779 \\
\hline & Within groups & 199.921 & 199 & 1.005 & & \\
\hline & Total & 200.000 & 200 & & & \\
\hline \multirow{3}{*}{ Factor 5 for analysis $6 *$ Prime } & Between groups & 8.475 & 1 & 8.475 & 8.806 & .003 \\
\hline & Within groups & 191.525 & 199 & .962 & & \\
\hline & Total & 200.000 & 200 & & & \\
\hline \multirow{3}{*}{ Factor 6 for analysis $6 *$ Prime } & Between groups & 4.786 & 1 & 4.786 & 4.879 & .028 \\
\hline & Within groups & 195.214 & 199 & .981 & & \\
\hline & Total & 200.000 & 200 & & & \\
\hline
\end{tabular}

\section{CONCLUSIONS}

This article discusses cultural appropriation, a practice that political correctness seeks to correct, which is widely talked about but still insufficiently researched. Until now, most of the academic debate about cultural appropriation has taken place in the humanities, mainly in the disciplines of anthropology and indigenous studies. Research on cultural appropriation in the context of marketing and branding and particularly in destination branding is virtually nonexistent. The main objective of this research was to examine consumers' knowledge of the concept of cultural appropriation and whether, where knowledge was lacking, exposure to information could significantly change attitudes toward it. Therefore, the 
investigation studied two phenomena: (a) cultural appropriation in a tourism context in the eyes of consumers and (b) the effect of advertising/education (priming) on consumers' assessment of the dimensions of cultural appropriation.

Initially, the investigation assumed that cultural appropriation, in the context of tourism, could be manifested by three dimensions or offerings typically available to tourists. The first dimension, The role and meaning of souvenirs sold to and bought by tourists, examined the role and meaning of souvenirs bought by tourists. The second dimension, The experience of tourists with local theatrical performances, examined the experience of tourists with local theatrical performances. The third dimension, The use of cultural artifacts by nonlocal people, examined the use of cultural artifacts by non-local people.

The goal was to verify that cultural appropriation could be defined by those three dimensions. However, after completing the study the variables were arranged in six factors. The grouping in six dimensions reflects the researchers' conclusion that the study participants are concerned with the well-being of local communities, but do not recognize the term cultural appropriation - the participants thus have a partial understanding of the concept of cultural appropriation. It should be noted that if cultural appropriation was a fully understood and accepted concept, there would be only three factors, not six. This is because the Factor 3 variables would be inserted in Factor 5, though with negative loadings, and the Factor 4 variables would be inserted in Factor 1, also with negative loadings. This assumption of negative loadings only occurs for variable 11 - "It is harmless when tourists use traditional objects from a culture in a different context such as to decorate their homes" - which is included in Factor 1 with a negative loading.

This assumption is reinforced by the different results associated with participants who read the priming text (the "priming" group) versus those who did not (the "non-priming" group). The "priming" group, who were asked to read a brief text about cultural appropriation before completing the questionnaire, displayed statistically significantly different attitudes toward two of the six factors examined. They seemed to be more sensitive to the concept of cultural appropriation and to the impact of theatrical performances on the local people and culture. No significant differences between the two groups were found regarding attitudes toward the sale and purchase of souvenirs and the use of outfits by outsiders of the culture. Conceivably, the lack of significant differences in the case of these dimensions could be explained by the fact that the text offered to the "priming" group did not include specific references about local people being affected or offended by the sales of reproductions of local art and objects or the use of local outfits and artifacts by outsiders, as it did in regard to the portrayal of local ceremonies by performers in venues such as hotels, theaters, etc.

Therefore, it is possible that tests specifically dealing with attitudes (1) toward souvenirs that are reproductions of local objects and art and (2) about the use of local outfits by outsiders and how members of the culture feel about that would yield different and statistically significant results between the two groups. The number of references in public discourse to cultural appropriation and negative reactions to how branding does not help preserve local cultures or benefit communities have increased in recent years. These concerns have affected mass media and even entertainment products as young content creators, who tend to be more accepting of this concept, enter the labour market. Nevertheless, from this study, it can be concluded that either consumers do not understand what cultural appropriation means or they do not accept the concept. The lack of understanding may be due to a lack of awareness of the potential negative impact of cultural appropriation on local communities. However, one also needs to consider: is the impact really negative? Further studies will be needed to understand the impact of cultural appropriation on local communities. It is critical to have the local communities' perspective on the use of their culture by other communities. Do they see this behavior as a positive or a negative? Only a few studies have assessed whether cultural appropriation really has a positive or negative impact on local communities. Furthermore, more studies that confront and clarify cultural appropriation versus cultural borrowing are needed.

Nonetheless, it is necessary to develop tools to ensure that the benefits of tourist consumption accrue to local communities. Several strategies have been developed and adopted by national, regional, and local governments to protect cultural elements, including intellectual property laws to protect local and indigenous art, music, rituals, creations, etc. from unauthorized use and commercial exploitation; requirements for the disclosure of information about the origin of souvenirs sold to tourists; seals of authenticity for local art and souvenirs; directives to display information about local artists who create works sold to tourists; consultation with and involvement of local community members in the development and performance of theatrical representations of local rituals and practices; educational materials explaining the meaning of local outfits and artifacts and how locals feel about the use of meaningful cultural elements out of context by outsiders. An example of a symbiotic relationship is that between Florida State University and the Seminole tribe in Florida. The Seminole Tribal Council drafted a resolution expressing their enthusiastic support for the use of the Seminole name, logos, and images by the university.

The action of the council was the outcome of the ongoing cooperation of the State of Florida with the tribe on two levels: (1) the participation of members of the tribe in many of the university's more significant events, and (2) advice and direction from the council to ensure tribal imagery is authentic (Florida State University, 2021). In fact, when the National Collegiate Athletic Association revised its guidelines on Native American nicknames in 2005, the Seminole Tribal Council unanimously approved a resolution supporting the use of the name by the Florida State University (Baker, 2020). It is evident that some social groups, including the media, are increasingly demanding political correctness from marketers. While criticism of cultural appropriation in the context of tourism may not yet have stopped a significant number of people from visiting popular destinations that have unique cultures, such as Mexico and Hawaii, the legal, ethical, and moral implications of cultural appropriation should not be ignored. It is crucial for scholars and practitioners to better understand cultural appropriation and its consequences, in the short and long term, to protect the reputations and thus preserve the attractiveness of destination brands. 


\section{REFERENCES}

Anderson, M. (2017). Twenty times Victoria's Secret put cultural appropriation on the runway. Revelist. https://www.revelist. com/styletrends/victorias-secret-cultural-appropriation/10413

Agarwal, S., \& Brunt, P. (2006). Social exclusion and English seaside resorts. Tourism Management, 27(4), 654-670. https://doi.org/10. 1016/j.tourman.2005.02.011

Bakare, L. (2020). Exeter to repatriate Blackfoot regalia to Siksika Nation. The Guardian. https://www.theguardian.com/world/2020 /apr/14/exeter-to-repatriate-blackfoot-regalia-to-siksika-nation

Baker, M. (2020). Why Florida State, Seminole Tribe stand behind the Seminoles nickname. Tampa Bay Times. https://www.tampabay. $\mathrm{com} /$ sports/seminoles/2020/07/10/why-florida-state-seminole-tribe-stand-behind-the-seminoles-nickname

Barbieri, C., \& Mahoney, E. (2010). Cultural tourism behaviour and preferences among the live-performing arts audience: An application of the univorous-omnivorous framework. International Journal of Tourism Research, 12(5), 481-496. https://doi.org/10.1002/jtr.767

Chapman, A., \& Speake, J. (2010). Regeneration in a mass-tourism resort: The changing fortunes of Bugibba, Malta. Tourism Management, 32(3), 482-491. https://doi.org/10.1016/j.tourman.2010.03.016

Crane, W. (2018). Cultural formation and appropriation in the era of merchant capitalism. Historical Materialism, 26(2), 242-270. https://doi.org/10.1163/1569206X-00001635

DeBoer, F. (2016). No one has the slightest idea what is and isn't cultural appropriation. http://fredrikdeboer.com

Ding, F. (2018). Developing e-commerce logistics in cross-border relation. Universitätsverlag der TU Berlin. https://depositonce.tuberlin.de/bitstream/11303/7351/6/ding_feng.pdf

Echtner, C.M., \& Brent Ritchie, J.R. (1993). The measurement of destination image: An empirical assessment. Journal of Travel Research, 31(3), 3-13. https://doi.org/10.1177/004728759303100402

Lavrakas, P.J. (Ed.). (2008). Encyclopedia of survey research methods. Sage. https://dx.doi.org/10.4135/9781412963947.n399

Fung, R. (1993). Working through cultural appropriation. FUSE 16(2-3), 16-24.

Freire, J. (2005). Geo-branding, are we talking nonsense? A theoretical reflection on brands applied to places. Place Branding, 1(4), 347-362. https://doi.org/10.1057/palgrave.pb.5990033

Freire, J.R., \& Gertner, R.K. (2021). The relevance of food for the development of a destination brand. Place Branding and Public Diplomacy, 17, 193-204. https://doi.org/10.1057/s41254-020-00164-5

Gertner, R.K. (2019). The impact of cultural appropriation on destination image, tourism, and hospitality. Thunderbird International Business Review, 61, 873-877. https://doi.org/10.1002/tie.22068

Gertner, R.K., \& Freire, J. (2018). Impact of place brand names on destination image. International Journal of Leisure and Tourism Marketing, 6(1), 39-50. https://doi.org/10.1504/IJLTM.2018.089223

Getz, D. (2008). Event tourism: Definition, evolution, and research. Tourism Management, 29(3), 403-428. https://doi.org/10. 1016/j.tourman.2007.07.017

Greenwood, D.J. (1989). Culture by the pound: An anthropological perspective on tourism as cultural commoditization. In Hosts and guests. The anthropology of tourism,2nd ed., 171-185, University of Pennsylvania Press, Philadelphia, USA.

Gursoy, D., Kim, K., \& Uysal, M. (2004). Perceived impacts of festivals and special events by organizers: An extension and validation. Tourism Management, 25(2), 171-181. https://doi.org/10.1016/S0261-5177(03)00092-X

Han, H.C. (2019). Moving from cultural appropriation to cultural appreciation. Art Education, 72(2), 8-13. https://doi.org/10. $1080 / 00043125.2019 .1559575$

Hart, J. (1997). Translating and resisting empire: cultural appropriation and postcolonial studies. In Borrowed power: Essays on cultural appropriation (pp. 137-168). Rutgers University Press, New Brunswick, USA.

Hassan, H. (2015). Social semiotics: Realizing destination image by means of cultural representations. International Journal of Social Science and Humanity, 5(1), 149-153. https://doi.org/10.7763/IJSSH.2015.V5.443

Heil, E. (2020). Quaker is dropping the Aunt Jemima image and name after recognizing they are 'based on a racial stereotype.' The Washington Post. https://www.washingtonpost.com/news/voraciously/wp/2020/06/17/quaker-is-dropping-the-aunt-jemima-imageand-name-after-recognizing-they-are-based-on-a-racial-stereotype/

Hernández-Mogollón, J.M., Duarte, P.A., \& Folgado-Fernández, J.A. (2018). The contribution of cultural events to the formation of the cognitive and affective images of a tourist destination. Journal of Destination Marketing and Management, 8, 170-178. https://doi.org/10.1016/j.jdmm.2017.03.004

Heyd, T. (2003). Rock art aesthetics and cultural appropriation. Journal of Aesthetics and Art Criticism, 61(1), 37-46. http://dx.doi.org/10.1111/1540-6245.0009

Hladki, J. (1994). Problematizing the issue of cultural appropriation. Alternate Routes: A Journal of Critical Social Research, 11, 95-119.

Hooks, B. (2006). Black looks: Race and representation. Academic Internet, Ventura, USA.

Indvik, L. (2013). Chanel (sort of) apologizes for controversial 'Cowboys and Indians' pre-fall collection. fashionista.com. https://fashionista.com/2013/12/chanel-apologizes-for-metiers-d-art-collection

Ivancevic, T.T., Jovanović, B., Djukic, S., Djukic, M., \& Markovic, S. (2008). Complex sports biodynamics: With practical applications in tennis (Vol. 2). Springer Science \& Business Media. https://doi.org/10.1007\%2F978-3-540-89971-6

Kulchyski, P. (1997). From appropriation to subversion: Aboriginal cultural production in the age of postmodernism. American Indian Quarterly, 21(4), 605-620. https://doi.org/10.2307/1185715

McFee, J.K., \& Degge, R.M. (1977). Art, culture, and environment: A catalyst for teaching. Wadsworth, Belmont, USA.

Leask, A. (2010). Progress in visitor attraction research: Towards more effective management. Tourism Management, 31(2), $155-166$. https://doi.org/10.1016/j.tourman.2009.09.004

Long, C. (2020). "The Conners" fans flip when Jackie gets stranded in Mexico. Popculture Com. https://popculture.com/tvshows/news/the-conners-jackie-mexico-season-2-finale-reactions/

Lynskey, D. (2014). This means war: Why the fashion headdress must be stopped. The Guardian. https://www.theguardian.com/fashion/ 2014/jul/30/why-the-fashion-headdress-must-be-stopped\#: :text=Last $\% 20$ week\%2C\%20the\%20organisers $\% 20$ told,on $\% 20$ the $\% 20$ festival's\%20Facebook\%20page

Malhotra, N.K., \& Dash, S. (2016). Marketing research: An applied orientation. Pearson.

Matthes, E.H. (2016). Cultural appropriation without cultural essentialism? Social Theory and Practice, 42(2), 343-366.

Matthes, E.H. (2019). Cultural appropriation and oppression. Philosophical Studies, 176, 1003-1013. https://doi.org/10.1007/s11098-018-1224-2 
McEvoy, J. (2020). Mrs. Butterworth's to undergo a "Complete Brand and Packaging Review” along with Aunt Jemima, Uncle Ben's. Forbes. https://www.forbes.com/sites/jemimamcevoy/2020/06/17/mrs-butterworths-to-undergo-a-complete-brand-and-packagingreview-along-with-aunt-jemima-uncle-bens/?sh=492402f05dc3

McLeod, S. (2017). Experimental design. www.simplypsychology.org. https://www.simplypsychology.org/experimental-designs.html

Molinillo, S., \& Japutra, A. (2015). Factors influencing domestic tourist attendance at cultural attractions in Andalusia. Journal of Destination Marketing and Management, 6(4), 456-464. https://doi.org/10.1016/j.jdmm.2016.09.011

Norris, M.L. (2020). Why did it take so long to set Aunt Jemima free?

O'Daly, B. (2017). ANAAY blasts dance group. Yale Daily News. https://yaledailynews.com/blog/2017/12/05/anaay-blasts-dance-group/

Perrett, C. (2020). Trump's Twitter account appears as the top result when users search the word 'racist'. Twitter says an algorithm is behind that 'recommendation.' Business Insider. https://www.businessinsider.com/twitter-shows-trumps-name-when-users-search-the-word-racist-2020-6.

Pomarico, N. (2020). Why everyone dressing up for Halloween needs to watch this week's "Conners" episode. Bustle. https://www. bustle.com/p/the-conners-halloween-episode-showed-that-cultural-appropriation-can-be-complicated-but-its-a-necessary-conversation-13043636

Rae, B. (2019). 14+ celebrities who have been accused of cultural appropriation. Crafty.Diply.com. https://crafty.diply.com/97145/14celebrities-who-have-been-accused-of-cultural-appropriation

Richards, G. (1996). Cultural tourism in Europe. CAB International, (Ed.)., Wallingford, UK.

Richards, G. (2003). What is cultural tourism? In Erfgoed voor Toerisme. Weesp: Nationaal Contact Monumenten (pp. 1-15).

Richards, G. (2005). Cultural tourism in Europe. The European Association for Tourism and Leisure Education (ATLAS), PDF (Original work published 1996), (Ed.). http://www.tram-research.com/cultural_tourism_in_europe

Richards, G., \& Wilson, J. (2004). The impact of cultural events on city image: Rotterdam, cultural capital of Europe 2001. Urban Studies, 41(10), 1931-1951. https://doi.org/10.1080/0042098042000256323

Rojekand, C., \& Urry, J. (1997). Touring cultures: Transformation of travel and theory. Routledge, London, UK.

Sanchez, R. (2020). NFL's Washington Redskins to change name following years of backlash. ABC News. https://abcnews.go.com/ US/washington-redskins-change-years- backlash/story?id=71744369\#: :text=The $\% 20$ team $\% 20$ has $\% 20$ not $\% 20$ released $\% 20$ what $\%$ 20the \%20new\%20name\%20will\%20be.\&text=Redskins\%20change\%20name\%20following\%20years\%20of\%20backlash.\&text=Th e\%20NFL's\%20Washington\%20Redskins\%20have,of\%20the\%20team's\%20name

Said, E.W. (1985). Orientalism reconsidered. Race \& Class, 27(2), 1-15. https://doi.org/10.2307/1354282

Scafidi, S. (2005). Who owns culture? Appropriation and authenticity in American law. Rutgers University Press, New Brunswick, USA.

Sdrali, D., \& Chazapi, K. (2007). Cultural tourism in a Greek insular community: The residents' perspective. Tourismos, 2(2), 61-75.

Twersky, C. (2019). 11 celebrities who have been accused of cultural appropriation. Seventeen. https://www.seventeen. com/celebrity/g22363821/cultural-appropriation-examples-celebrities/

Valinsky, J. (2020). The Aunt Jemima brand, acknowledging its racist past, will be retired. CNN Business. https://www.cnn.com/ 2020/06/17/business/aunt-jemima-logo-change/index.html

Valle, P.O., Guerreiro, M., Mendes, J., \& Silva, J.A. (2011). The cultural offer as a tourist product in coastal destinations: The case of Algarve, Portugal. Tourism and Hospitality Research, 11(4), 233-247. https://doi.org/10.1177/1467358411420623

Wang, C.Y.J. (2001). Handshakes in cyberspace: Bridging the cultural differences through effective intercultural communication and collaboration. In 2001 Annual Proceedings - Atlanta: Volume \#2 (pp. 513-520). Nova Southeastern University, North Miami Beach, USA.

Wesaw, M. (1994). Finders keepers? Adulteration of Native American cultures in the name of profit. Cultural Survival. https://www.culturalsurvival.org/publications/cultural-survival-quarterly/finders-keepers-adulteration-native-american-cultures-name

Wu, K.J. (2020). Land O’Lakes drops the iconic logo of an indigenous woman from its branding. Smithsonian Magazine. https://www. smithsonianmag.com/smart-news/mia-land-olakes-iconic-indigenous-woman-departs-packaging-mixed-reactions-180974760/

Young, C. (2015). To the new culture cops, everything is appropriation. The Washington Post. https://www.washingtonpost.com/ posteverything/wp/2015/08/21/to-the-new-culture-cops-everything-is-appropriation/

Young, J.O. (2005). Profound offense and cultural appropriation. Journal of Aesthetics and Art Criticism, 63(2), $135-146$.

Young, J.O. (2010). Cultural appropriation and the arts. Wiley-Blackwell, Malden, USA.

Young, J.O., \& Brunk, C.G. (2009). The ethics of cultural appropriation. Wiley-Blackwell, Malden, USA.

*** Florida State University (2021). Relationship with the Seminole Tribe of Florida. https://unicomm.fsu.edu/messages/relationshipseminole-tribe-florida/

*** Harper's BAZAAR. (2017). Victoria's Secret is being accused of cultural appropriation yet again. Harper's Bazaar. https://www.harpersbazaar.com/uk/

*** Lexico.com (n.d.) Political correctness. In Oxford English and Spanish Dictionary, Thesaurus, and Spanish to English Translator. Retrieved July 16, 2020, from https://www.lexico.com/definition/political_correctness

*** NITV. (2017). Fake Aboriginal art bill boomerangs back into Parliament. NITV. https://www.sbs.com.au/nitv/nitv-news/article/2017 /09/11/fake-aboriginal-art-bill-boomerangs-back-parliament

*** The Washington Post. https://www.washingtonpost.com/opinions/why-did-it-take-so-long-to-set-aunt-jemima-free/2020/06/17/ 788d0112-b0db-11ea-8758-bfd1d045525a_story.html

Article history: Received: 03.09.2021 Revised: 06.12.2021 Accepted: 03.01.2022 Available online: 28.01.2022 